\title{
POLA ALIRAN DUA FASE GAS - FLUIDA NON NEWTONIAN MELALUI BELOKAN PIPA
}

Two-phase flow applications can be used in chemical reactors, fuel cell and a cooler of electronic devices. Nowadays, the study on multiphase flow is concern with the gas-non Newtonian liquids flow. Since, non-Newtonian liquids commonly used in both industrial and medical applications such as blood flow, polymer and chemical solutions. The viscosity of a non-Newtonian liquid cannot be described by Newton's law viscosity. The viscosity will affect flow behavior in pipes depends on the rheology of the fluid. The purpose of this study is to further investigate the flow pattern characteristic of gas-Newtonian/non-Newtonian liquid two-phase flows in a normal channel. Ultrapure water, polyacrylamide aqueous solutions (PAM) were used as test fluids, while argon gas as the test gas. Liquid and gas were introduced in T-junction, which placed on the upstream of the test section. In this study, the polyacrylamide concentration was variated on $0.1 \% \mathrm{wt}$ and $0.4 \%$ wt. Moreover, the flow rate of liquids tested were variated on $0.1167 \mathrm{~m}^{3} / \mathrm{s}, 0.183 \mathrm{~m}^{3} / \mathrm{s}, 0.25 \mathrm{~m}^{3} / \mathrm{s}$; and $0.283 \mathrm{~m}^{3} / \mathrm{s}$. Therefore, the gas tested was variated on $0.083 \mathrm{~m}^{3} / \mathrm{s}, 0.167 \mathrm{~m}^{3} / \mathrm{s}$, and $0.25 \mathrm{~m}^{3} / \mathrm{s}$. The circular channel and bend pipe were used in this study, which has hydraulic diameter of $25.4 \mathrm{~mm}$. The high-speed video camera was used to record the flow patterns in the bend as the test section. The flow pattern, bubble length, bubble velocity and void fraction were determined by analyzing the video image of the flows. Slug and plug flow patterns mostly appear in this study for each variation of liquids tested. Increasing gas superficial velocity induced the longer bubble. Furthermore, because of the higher viscosity of the non-Newtonian liquid, the bubble nose of gas-non Newtonian liquid two-phase flow becomes sharper than the bubble nose of gas-Newtonian liquid two-phase flow.

Keywords: Two-Phase Flow, Non-Newtonian, Flow Pattern, Superficial Velocity, Bubble Length, Void Fraction

\section{PENDAHULUAN}

Aliran dua fase merupakan aliran simultan dari dua fluida yang terpisah satu sama lain baik itu fluida cair dengan gas maupun fluida cair atau gas dengan partikel padat yang telah tersuspensi. Pada aliran dua fase terdapat banyak fenomena yang lebih banyak dan lebih kompleks dibandingkan aliran satu fase diantaranya pada aliran dua fase ialah interaksi antar fase, pengaruh deformasi permukaan dan permukaan fluida, pengaruh ketidakseimbangan fase, perubahan pressure drop, dan lain sebagainya. Pada aliran satu fase hanya terdapat pressure drop, yang dipengaruhi oleh bilangan Reynolds yang merupakan fungsi dari kecepatan fluida, viskositas kinematik fluida, dan diameter pipa. Sedangkan pada aliran dua fase didalam saluran tertutup (pipa) tidak hanya dipengaruhi bilangan Reynolds tetapi juga ikatan antar fase yang bereaksi mempunyai pengaruh signifikan. Sehingga akan terbentuk bermacam-macam flow regime (flow pattern) akibat interaksi yang terjadi antar fase tersebut. Aliran yang mengalami perubahan flow regime (flow pattern) dapat menyebabkan pressure drop yang berubah-ubah atau berfluktuasi [1]

Karakterisitk aliran dua fase melewati sudden contraction dalam microchannel dengan bentuk saluran persegi. Cairan yang digunakan adalah distilled water, ethanol 49\% berat, ethanol murni dan HFE7200. Sedangkan gas yang digunakan adalah nitrogen. Dalam penelitian ini, dihasilkan dua pola aliran yaitu quasihomogeneous dan quasi separated. Quasi homogeneous memperlihatkan bentuk dan panjang bubble yang 
seragam sedangkan quasi separated memperlihatkan bentuk dan panjang bubble yang tidak seragam. Dua pola aliran ini sangat dipengaruhi oleh perbedaan properti dari cairan uji, khususnya viskositas dan tegangan permukaan, karena saluran uji yang digunakan berukuran mikro yaitu sebesar 0.53 atau $0.78(\mathrm{~mm})$ untuk lebar penampang saluran dan $0.24(\mathrm{~mm})$ tinggi penampang saluran. Tidak ada efek dari contraction ratio yang digunakan dalam penelitian ini. Variasi jenis cairan uji menunjukkan bahwa, cairan uji dengan densitas yang besar menghasilkan pressure drop yang besar pula [2].

Saluran yang biasa digunakan dalam dunia industri saat ini masih berupa saluran normal dengan luas penampang lingkaran yang ukuran diameter dalamnya minimal $2.54 \mathrm{~cm}$. Beberapa penelitian aliran dua fase telah dilakukan pada saluran normal. Analisis aliran fluida dua fase (udara-air) melalui belokan $45^{\circ}$ telah dilakukan untuk mengetahui pengaruh belokan terhadap pola aliran dua fase. Hasil yang didapat adalah, tidak ada efek belokan terhadap pola aliran dua fase. Pola aliran yang didapat berbentuk slug dan plug. Pola aliran ini dipengaruhi oleh besar fraksi volume gas yang dipengaruhi oleh debit udara. Semakin besar fraksi volume gas disetiap debit gas meyebabkan pressure drop aliran dua fase yang melewati belokan $45^{\circ}$ mengalami penurunan [3].

Pada penelitian-penelitian aliran dua fase gas-liquid sebelumnya banyak dilakukan terhadap aliran dua fase gas-liquid dengan menggunakan fluida Newtonian. Air atau cairan refrigeran yang merupakan fluida Newtonian sering digunakan sebagai cairan untuk aliran dua fase. Sedangkan, fluida non-Newtonian terdapat hampir di seluruh aplikasi bidang industri dan biomedik seperti darah di dalam pembuluh darah, air limbah, larutan polimer, larutan kimia, dan lain-lain. Viskositas dari fluida non-Newtonian proporsional terhadap gaya geser. Hubungan terhadap gaya geser dengan viskositas cairan bergantung dari jenis fluida tersebut. Saat viskositas berkurang seiring dengan meningkatnya gaya geser, cairan tersebut disebut sebagai cairan shearthinning fluids. Sebaliknya, saat viskositas bertambah seiring dengan meningkatnya gaya geser maka, cairan tersebut dinamakan shear-thickening non-Newtonian fluid. Pada dunia perindustrian, shear-thinning fluids lebih sering ditemukan dibandingkan dengan shear-thickenning fluids.

Karakteristik aliran dua fase nitrogen-fluida non Newtonian $(0.4 \%$ carboxymethyl cellulose, $0.2 \%$ polyacrylamide, dan $0.2 \%$ xanthan gum) telah diteliti di dalam microchannel berukuran $0.886 \mathrm{~mm} ; 1.886 \mathrm{~mm}$; dan $2.886 \mathrm{~mm}$. Flow pattern dan flow transition map di teliti dalam penelitian ini. Jenis aliran dua fase yang terjadi meliputi aliran slug, aliran churn, dan aliran annular [4].

Karakteristik aliran dua fase gas/cairan yang melalui circular microchannel dengan diameter $0.25 \mathrm{~mm}$ dengan jenis cairan uji yang berbeda yaitu polyacrylamide dengan variasi $0.1 \%$ PAM; $0.2 \%$ PAM; dan $0.4 \%$ PAM juga telah diteliti. Fluida gas yang digunakan adalah Nitrogen. Karakteristik yang ditekankan pada penelitian ini adalah bagaimana pengaruh fluida dengan sifat viscoelastic terhadap pressure drop yang akan terjadi [5].

Selain itu, karakterisitk aliran dua fase gas - non-Newtonian liquid di dalam microchannel berbentuk persegi juga telah diteliti. Larutan polyacrylamide (PAM) digunakan sebagai fluida cair dan nitrogen sebagai fluida gas. Konsentrasi larutan PAM divariasikan sebesar 0.1\% PAM; 0.2\% PAM; dan 0.4\% PAM. Pola aliran yang terjadi pada penelitian ini hanya slug. Kecepatan bubble meningkat seiring meningkatnya konsentasi larutan PAM sedangkan void fraction menurun [6].

Pada umumnya, pipa yang digunakan dalam instalasi pemipaan di industri memiliki penampang berbentuk lingkaran dengan ukuran pipa normal dengan ukuran diameter dalam minimal sebesar $2.54 \mathrm{~cm}$. Untuk itu, pola aliran fluida dua fase gas-cairan non Newtonian dalam pipa maupun instalasi pemipaan seperti belokan pipa perlu diteliti. Berikut parameter-parameter aliran dua fase dalam penelitian ini.

a. Bilangan Reynolds

Bilangan Reynolds merupakan suatu parameter yang menyatakan suatu perbandingan kecepatan aliran, dan ukuran yang mewakili diameter penampang yang dilewati aliran fluida terhadap viskositas kinematic fluida. Besar bilangan Reynolds membedakan jenis aliran laminar, transisi atau turbulen pada lapisan batas, didalam pipa atau disekitar benda yang terendam. dimana parameter-parameter yang mempengaruhinya adalah densitas, kecepatan, dan viskositas daripada fluida cair tersebut. Bilangan Reynolds dibagi menjadi dua kategori, yaitu bilangan Reynolds fluida cair dan bilangan Reynolds fluida gas. Bilangan Reynolds pada fluida cair dan fluida gas dapat dirumuskan seperti pada Persamaan 1.

1. Bilangan Reynolds fluida cair non-Newtonian.

$$
R e_{L}=\frac{8^{1-n} \cdot \rho_{L} \cdot D^{n} \cdot j_{L}^{2-n}}{\mathrm{~K}}\left(\frac{n}{a+b n}\right)^{n}
$$


Dengan:

$\mathrm{a}=0.25$

$\mathrm{b}=0.75$

Keterangan:

$\operatorname{Re}_{\mathrm{L}}=$ Bilangan Reynolds fluida cair

$\rho_{\mathrm{L}} \quad=$ Densitas fluida cair $\left(\mathrm{kg} / \mathrm{m}^{3}\right)$

$\mathrm{j}_{\mathrm{L}} \quad=$ Kecepatan fluida cair $(\mathrm{m} / \mathrm{s})$

$\mathrm{D}=$ Diameter pipa $(\mathrm{m})$

$\mu_{\mathrm{L}} \quad=$ Viskositas fluida cair $\left(\mathrm{N} . \mathrm{s} / \mathrm{m}^{2}\right)$

$\mathrm{a}, \mathrm{b}, \mathrm{K}, \mathrm{n}=$ konstanta fluida non-Newtonian

Tabel 1. Rheological parameters, $\mathrm{K}$ dan $\mathrm{n}$.

\begin{tabular}{ccc}
\hline Cairan & K [Pa.s $\left.{ }^{\mathbf{n}}\right]$ & $\mathbf{n}[-]$ \\
\hline Air & 0,00097 & 1,00 \\
PAM 0,1 wt\% & 0,0015 & 1,00 \\
PAM 0,4 wt\% & 0,013 & 0,87
\end{tabular}

Sumber: [5]

2. Bilangan Reynolds fluida gas.

$$
R e_{G}=\frac{\rho G . j G . D}{\mu_{G}}
$$

Keterangan:

$$
\begin{aligned}
& \operatorname{Re}_{\mathrm{G}}=\text { Blangan Reynolds fluida gas } \\
& \rho_{\mathrm{G}} \quad=\text { Densitas fluida gas }\left(\mathrm{kg} / \mathrm{m}^{3}\right) \\
& \mathrm{j}_{\mathrm{G}} \quad=\text { Kecepatan fluida gas }(\mathrm{m} / \mathrm{s}) \\
& \mathrm{D} \quad=\text { Diameter pipa }(\mathrm{m}) \\
& \mu_{\mathrm{G}} \quad=\text { Viskositas fluida gas }\left(\mathrm{N} . \mathrm{s} / \mathrm{m}^{2}\right)
\end{aligned}
$$

b. Bilangan Weber

Bilangan Weber merupakan bilangan yang menunjukkan perbandingan dari gaya inersia terhadap kekuatan tegangan permukaan. Bilangan Weber dibagi menjadi dua kategori, yaitu bilangan Weber pada fluida cair dan fluida gas. Rumus bilangan Weber dapat dituliskan pada Persamaan 3 dan 4, berturut-turut.

1. Bilangan Weber fluida cair

$$
W e_{L}=\frac{\rho L . j L^{2} . D}{\sigma}
$$

2. Bilangan Weber fluida gas

$$
W e_{G}=\frac{\rho G \cdot j G^{2} \cdot D}{\sigma}
$$

Keterangan:

$\mathrm{We}_{\mathrm{L}}$ = Bilangan Weber fluida cair 


$$
\begin{array}{ll}
\mathrm{We}_{\mathrm{G}} & =\text { Bilangan Weber fluida gas } \\
\rho_{\mathrm{L}} & =\text { Densitas fluida cair }\left(\mathrm{kg} / \mathrm{m}^{3}\right) \\
\rho_{\mathrm{G}} & =\text { Densitas fluida gas }\left(\mathrm{kg} / \mathrm{m}^{3}\right) \\
\mathrm{j}_{\mathrm{L}} & =\text { Kecepatan fluida cair }(\mathrm{m} / \mathrm{s}) \\
\mathrm{j}_{\mathrm{G}} & =\text { Kecepatan fluida gas }(\mathrm{m} / \mathrm{s}) \\
\mathrm{D} & =\text { Diameter pipa }(\mathrm{m}) \\
\sigma & =\text { Tegangan Geser }\left(\mathrm{N} / \mathrm{m}^{2}\right)
\end{array}
$$

c. Bilangan Bond

Bilangan Bond pada Persamaan 5 merupakan bilangan yang menunjukkan perbandingan dari percepatan gravitasi terhadap kekuatan tegangan permukaan.

$$
B o=\frac{\left(\rho_{L}-\rho_{G}\right) \cdot g \cdot D^{2}}{\sigma}
$$

Keterangan:

$$
\begin{aligned}
& \text { Bo }=\text { Bilangan Bond } \\
& \rho_{\mathrm{L}}=\text { Densitas fluida cair }\left(\mathrm{kg} / \mathrm{m}^{3}\right) \\
& \rho_{\mathrm{G}}=\text { Densitas fluida gas }\left(\mathrm{kg} / \mathrm{m}^{3}\right) \\
& \mathrm{g} \quad=\text { Percepatan gravitasi bumi }=9,81 \mathrm{~m} / \mathrm{s}^{2} \\
& \mathrm{D}=\text { Diameter pipa }(\mathrm{m}) \\
& \sigma \quad=\text { Tegangan Geser }\left(\mathrm{N} / \mathrm{m}^{2}\right)
\end{aligned}
$$

\section{d. Bubble Velocity}

Merupakan penjumlahan daripada kecepatan fluida cair dan fluida gas. Rumus bubble velocity dituliskan pada Persamaan 6.

$$
\begin{aligned}
& u_{G}=j \\
& j=j_{G}+j_{L}
\end{aligned}
$$

Keterangan:

$\mathrm{u}_{\mathrm{G}}=$ Bubble velocity $(\mathrm{m} / \mathrm{s})$

$\mathrm{j}=$ Superficial velocity $(\mathrm{m} / \mathrm{s})$

$\mathrm{j}_{\mathrm{L}}=$ kecepatan fluida cair $(\mathrm{m} / \mathrm{s})$

$\mathrm{j}_{\mathrm{G}}=$ kecepatan fluida gas $(\mathrm{m} / \mathrm{s})$

\section{e. Void Fraction}

Void fraction adalah perbandingan luas aliran fluida gas dengan luas total aliran fluida gas dan fluida cair yang dapat dihitung menggunakan Persamaan 8 .

$$
\alpha=\frac{A_{G}}{A}
$$

Dimana kecepatan superfisial gas, $j_{G}$ dan kecepatan rata-rata fase gas, $u_{G}$ dapat dihitung menggunakan Persamaan 9 dan 10. 


$$
\begin{aligned}
& j_{G}=\frac{Q_{G}}{A} \\
& u_{G}=\frac{Q_{G}}{A_{G}}
\end{aligned}
$$

Sehingga, untuk mendapatkan void fraction, $\alpha$ dapat menggunakan Persamaan 11 yang merupakan hasil substitusi Persamaan 9 dan 10.

$$
\alpha=\frac{j_{G}}{u_{G}}
$$

Pada penelitian ini, data void fraction akan dibandingkan dengan data void fraction untuk aliran dua fase nitrogen-air pada pipa circular berdiameter $100 \mu$ m yaitu Persamaan 12 [7].

$$
\begin{aligned}
& \alpha=\frac{0,03 \beta^{0,5}}{1-0,97 \beta^{0,5}} \\
& \beta=\frac{Q_{G}}{Q_{G}+Q_{L}}
\end{aligned}
$$

Keterangan:

$\alpha=$ Void fraction

$\beta=$ Volumetric Quality

\section{f. Parameter Lockhart-Martinelli}

Parameter Lockhart-Martinelli merupakan perbandingan dari beda tekanan fluida cair dengan fluida gas yang dituliskan pada Persamaan 14.

$$
\mathrm{X}^{2}=(\Delta \mathrm{P})_{\mathrm{L}} /(\Delta \mathrm{P})_{\mathrm{G}}
$$

Keterangan:

$\mathrm{X} \quad=$ Parameter Lochart-Martinelli

$(\Delta \mathrm{P})_{\mathrm{L}}=$ Frictional pressure drop pada fluida cair

$(\Delta \mathrm{P})_{\mathrm{G}}=$ Frictional pressure drop pada fluida gas

\section{g. Panjang Bubble}

Parameter panjang bubble per diameter pipa, $L_{G} / D$ merupakan parameter non dimensional yang dihubungkan dengan rasio debit gas terhadap debit fluida cair, $Q_{G} / Q_{L}$. Hal tersebut dikarenakan panjang bubble akan terpengaruh oleh kecepatan masing-masing fase baik gas maupun cairan yang mengalir dalam sebuah pipa. Pada penelitian ini, hubungan antara panjang bubble dan rasio debit fluida dibandingkan dengan korelasi dengan hasil pola aliran homogeneous meliputi pola aliran slug dan plug seperti ditunjukkan pada Persamaan $15[8]$.

$$
\frac{L_{G}}{W}=\left(1+\frac{Q_{G}}{Q_{L}}\right)
$$

\section{METODE DAN BAHAN}

Penelitian ini dilakukan untuk mengetahui karakteristik aliran dua fase gas-cairan non Newtonian melalui belokan pipa, meliputi pola aliran, bubble velocity, dan void fraction. Fluida non Newtonian yang digunakan adalah PAM dan argon sebagai gas uji. Tabel 2 menunjukkan data propertis dari jenis-jenis fluida yang digunakan dalam penelitian ini. 
Tabel 2. Propertis fluida

\begin{tabular}{lllll}
\hline Cairan & Densitas, $\boldsymbol{\rho}_{\boldsymbol{L}}\left[\frac{\mathrm{kg}}{\mathrm{m}^{3}}\right]$ & Tegangan Permukaan, $\boldsymbol{\sigma}\left[\frac{\mathrm{N}}{\mathrm{m}}\right]$ & $\mathbf{K}\left[\right.$ Pa.s $\left.{ }^{\mathbf{n}}\right]$ & $\mathbf{n}[-]$ \\
\hline Air & 998 & 0.072 & 0,00097 & 1,00 \\
PAM 0,1 wt\% & 998 & 0.072 & 0,0015 & 1,00 \\
PAM 0,4 wt\% & 999 & 0.073 & 0,013 & 0,87 \\
\hline
\end{tabular}

Pada penelitian ini, konsentrasi PAM divariasikan sebesar $0.1 \%$ dan $0.4 \%$. Debit fluida cair divariasikan sebesar $0.1167 \mathrm{~m}^{3} / \mathrm{s}, 0.183 \mathrm{~m}^{3} / \mathrm{s}, 0.25 \mathrm{~m}^{3} / \mathrm{s}$; dan $0.283 \mathrm{~m}^{3} / \mathrm{s}$ dengan mengatur bukaan katup pada discharge pompa dan diukur menggunakan digital flowmeter. Sedangkan debit yang digunakan untuk fluida gas adalah $0.083 \mathrm{~m}^{3} / \mathrm{s}, 0.167 \mathrm{~m}^{3} / \mathrm{s}$, dan $0.25 \mathrm{~m}^{3} / \mathrm{s}$ dengan mengatur bukaan katup pada tabung gas dan diukur menggunakan mass flow meter. Pipa uji yang digunakan dalam penelitian adalah pipa stainless steel ST304 dan belokan pipa yang terbuat dari akrilik berdiameter $25.4 \mathrm{~mm}$ dan sudut belokan sebesar $90^{\circ}$, tipe peletakan titik pengukuran yang digunakan yaitu tipe corner taps, sistem saluran diasumsikan adiabatik. Aliran dua fase terbentuk dari campuran fluida gas dan cair yang dialirkan pada pipa dan dipertemukan melalui sambungan T yang diletakkan di bagian hulu belokan sebelum memasuki area uji. Pola aliran yang terjadi pada belokan pipa divisualisasikan menggunakan kamera Ultraspeed. Instalasi penelitian yang digunakan ditunjukkan pada Gambar 1. Pola aliran dua fase gas-cairan non Newtonian dipengaruhi oleh propertis fluida yang digunakan dalam penelitian.

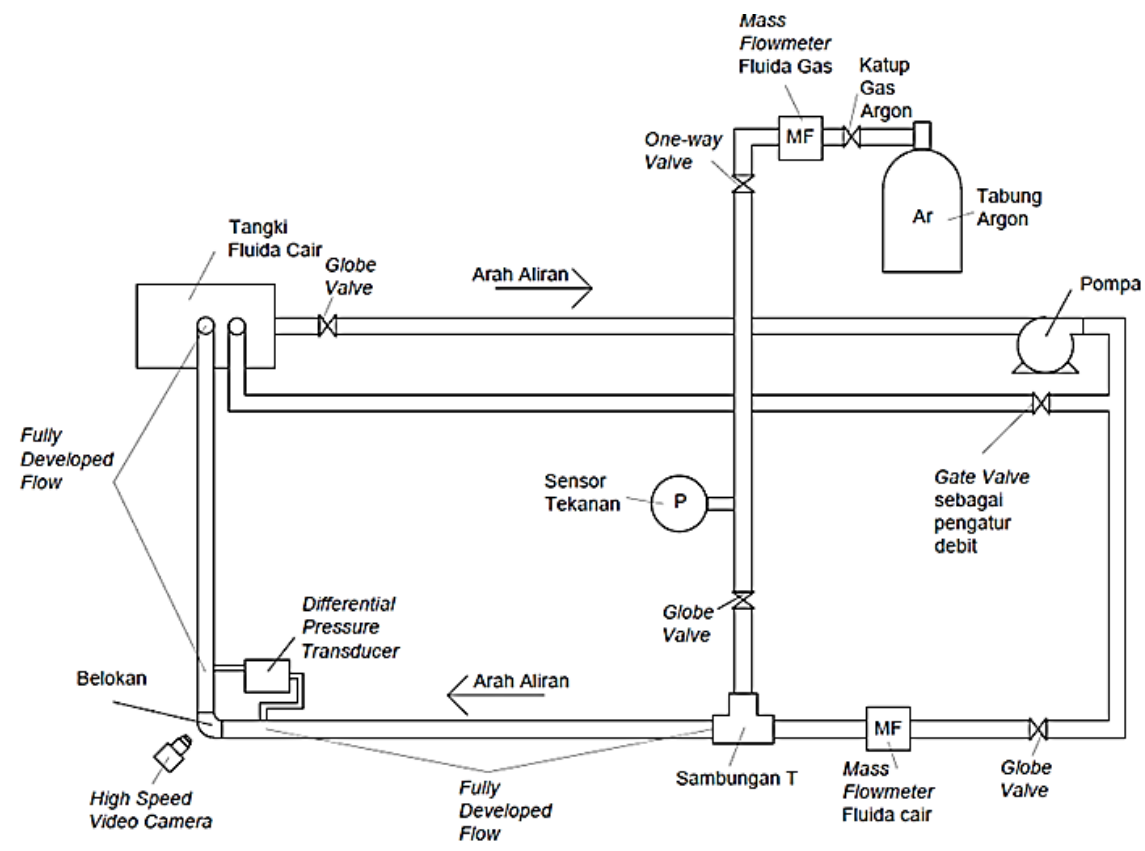

Gambar 1. Skema Instalasi Penelitian

Metode Pengukuran Panjang Bubble dan Liquid Slug dilakukan dengan memisualisasikan pola aliran dua fase gas-cairan non Newtonian pada penelitian ini direkam menggunakan High Speed Video Camera. Data video diolah menggunakan ImageJ untuk mendapatkan beberapa karakteristik aliran dua fase seperti kecepatan bubble, $u_{G}$ yang dapat dihitung berdasarkan Persamaan 16.

$$
u_{G}=\Delta Z \cdot F
$$

keterangan,

$u_{G}=$ kecepatan bubble $\left[\frac{\mathrm{m}}{\mathrm{s}}\right]$

$\Delta Z=$ perpindahan bubble nose selama $\frac{1}{F}[\mathrm{~m}]$

$F=$ frame rate $\left[\frac{\text { frame }}{\mathrm{s}}\right]$ 


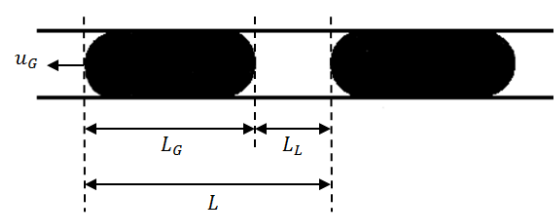

Gambar 2. Diagram skematik pengukuran panjang bubble dan liquid slug kut:

Panjang bubble dan liquid slug didapatkan dengan menggunakan Persamaan 17 dan 18 [9] sebagai beri-

$L_{G}=\frac{u_{G}\left(f_{G, i}-f_{G, 0}\right)}{F}$

$L_{L}=\frac{u_{G}\left(f_{L, i}-f_{L, O}\right)}{F}$

Dimana

$f_{G, i}=$ merupakan nomor frame disaat ekor bubble muncul

$f_{L, i}=$ merupakan nomor frame disaat ekor liquid slug muncul

$f_{G, o}=$ merupakan nomor frame disaat ekor bubble hilang

$f_{L, o}=$ merupakan nomor frame disaat ekor liquid slug hilang

\section{HASIL DAN DISKUSI}

Penelitian ini menggunakan air, PAM 0.1 wt $\%$, dan PAM 0.4 wt $\%$ sebagai cairan uji dan Argon sebagai gas uji. Gas Argon dan masing-masing cairan uji di campur pada $T$-jucntion kemudian dialirkan melalui belokan pipa. Pola aliran dua fase yang terjadi di daerah sebelum belokan pipa, belokan pipa maupun setelah belokan pipa hanya meliputi pola aliran slug dan plug untuk masing-masing jenis cairan yang digunakan dengan setiap variasi debit gas maupun cairan. Pola-pola aliran tersebut ditunjukkan pada Gambar 3-5 yang diambil dari pandangan atas di daerah-daerah yang diperhitungkan aliran sudah berkembang penuh (fully developed flow). Nose bubble yang terbentuk pada aliran dua fase argon-cairan non Newtonian lebih panjang dan lebih tajam dibandingkan dengan bubble yang terbentuk pada aliran dua fase argon-air. Hal ini dikarenakan lapisan film cairan non Newtonian di sekitar bubble lebih tebal akibat viskositas yang tinggi seperti pada Gambar 3.

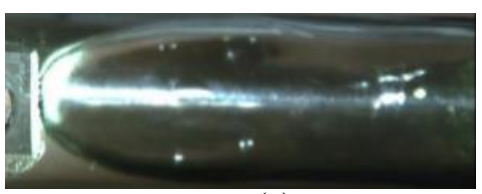

(a)

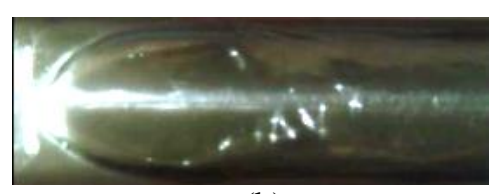

(b)

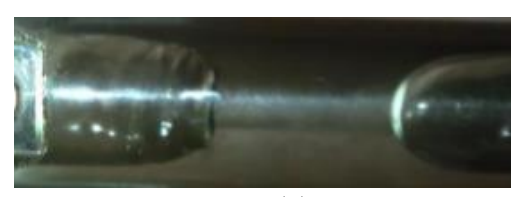

(c)

Gambar 3. Pola Aliran Slug pada Aliran Dua Fase gas-cairan non Newtonian Sebelum Belokan Pipa dengan Debit Gas sebesar $0.25 \mathrm{~m}^{3} / \mathrm{s}$ dan Debit Cairan sebesar $0.1167 \mathrm{~m}^{3} / \mathrm{s}$ untuk Variasi Jenis Cairan (a) Air, (b) PAM $0.1 \mathrm{wt} \%$, dan (c) PAM $0.4 \mathrm{wt} \%$.

Pengaruh instalasi pemipaan juga mempengaruhi panjang bubble seperti saat aliran dua fase melewati belokan pipa. Saat aliran melewati daerah sebelum belokan, terlihat bubble memenuhi dinding pipa, namun ketika melewati belokan, bubble seperti tertarik dan menyempit bagian nosenya karena efek perubahan kecepatan cairan melewati belokan seperti terlihat pada Gambar 4. Bubble berubah kembali diameternya memenuhi dinding pipa didaerah setelah belokan setelah terbentuk fully developed flow seperti pada Gambar 5 . 


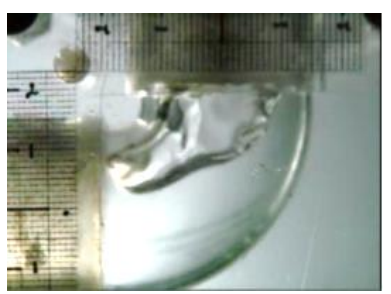

(a)

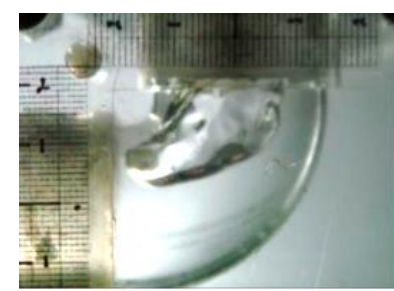

(b)

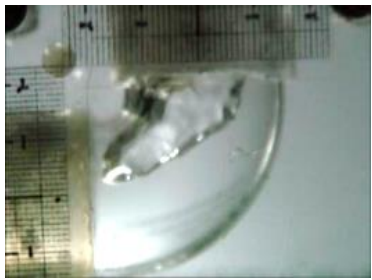

(c)

Gambar 4. Pola Aliran Slug pada Aliran Dua Fase gas-cairan non Newtonian di Belokan Pipa dengan Debit Gas sebesar $0.25 \mathrm{~m}^{3} / \mathrm{s}$ dan Debit Cairan sebesar $0.1167 \mathrm{~m}^{3} / \mathrm{s}$ untuk Variasi Jenis Cairan (a) Air, (b) PAM 0.1 wt $\%$, dan (c) PAM 0.4 wt $\%$.

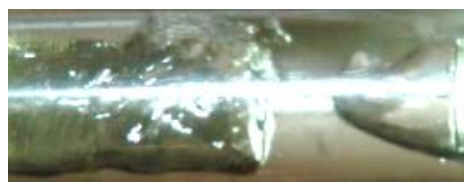

(a)

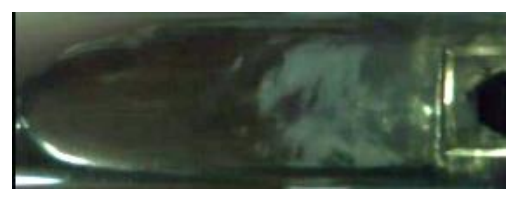

(b)

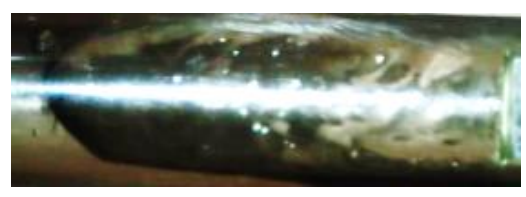

(c)

Gambar 5. Pola Aliran Slug pada Aliran Dua Fase gas-cairan non Newtonian Setelah Belokan Pipa dengan Debit Gas sebesar $0.25 \mathrm{~m}^{3} / \mathrm{s}$ dan Debit Cairan sebesar $0.1167 \mathrm{~m}^{3} / \mathrm{s}$ untuk Variasi Jenis Cairan (a) Air, (b) PAM 0.1 wt $\%$, dan (c) PAM 0.4 wt $\%$.

Semakin tinggi rasio kecepatan superfisial gas terhadap cairan semakin panjang bubble untuk setiap jenis cairan uji. Untuk aliran dua fase argon-cairan non Newtonian, panjang bubble semakin pendek seiring bertambahnya konsentrasi larutan polyacrylamide seperti ditunjukkan pada Gambar 6. Panjang bubble dipengaruhi oleh momentum bubble, tegangan permukaan, gaya inersia dan gaya drag [10].

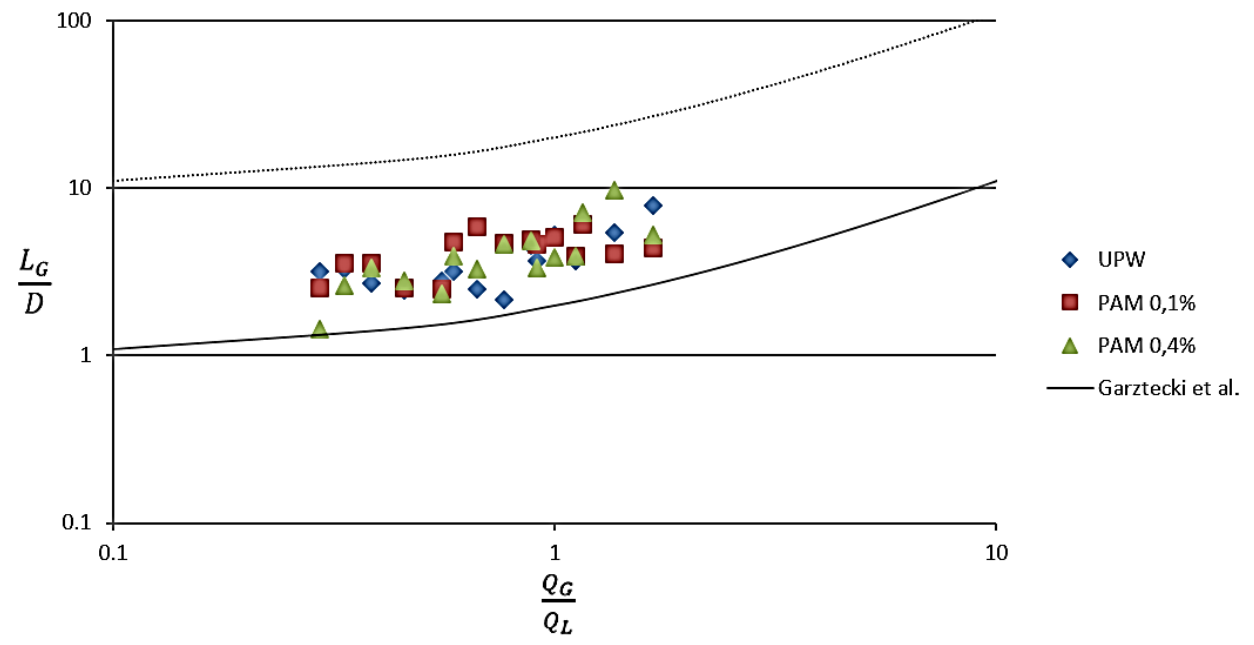

Gambar 6. Grafik Hubungan Panjang Bubble dengan Rasio Debit Gas dan Cairan untuk Variasi Cairan Uji.

Void fraction adalah perbandingan luas aliran fluida gas dengan luas total aliran fluida gas dan fluida cair. Data void fraction dalam penelitian ini seperti pada Gambar 7 dibandingkan dengan pola aliran homogeneous $(\alpha=\beta)$ yang ditunjukkan dengan garis lurus, $\alpha=0.833 \beta$ yang ditunjukkan dengan dot line [11], dan persamaan untuk aliran dua fase nitrogen-water di pipa circular, $\alpha=\varangle 0,03 \beta \rrbracket^{\wedge} 0,5 /\left(1-\quad\left[0,97 \beta \rrbracket^{\wedge} 0,5\right)\right.$ yang ditunjukkan dengan dash-dot line [7]. Data penelitian aliran dua fase argon-cairan non Newtonian untuk masing-masing jenis cairan uji mendekati pola aliran homogeneous meliputi pola aliran slug dan plug. 


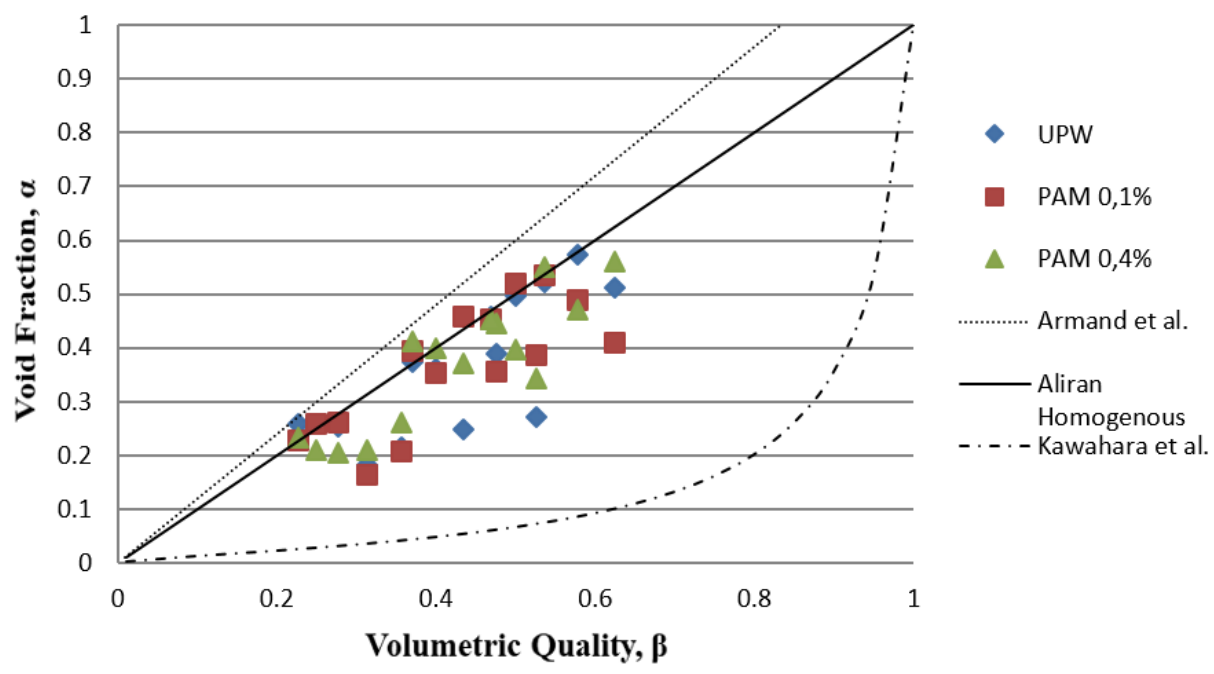

Gambar 7. Grafik Hubungan Void Fraction dengan Volumetric Quality untuk Variasi Cairan Uji.

\section{KESIMPULAN}

Berdasarkan analisis yang telah dilakukan dalam penelitian ini dapat disimpulkan bahwa:

1. Pola aliran yang terbentuk pada aliran dua fase argon-cairan non Newtonian untuk setiap jenis cairan uji (air, PAM $0.1 \mathrm{wt} \%$, PAM $0.4 \mathrm{wt} \%$ ) adalah pola aliran slug dan plug.

2. Semakin tinggi rasio kecepatan superfisial gas terhadap cairan, semakin panjang bubble untuk setiap jenis cairan uji.

3. Nose bubble yang terbentuk pada aliran dua fase argon-cairan non Newtonian lebih panjang dan lebih tajam dibandingkan dengan bubble yang terbentuk pada aliran dua fase argon-air. Hal ini dikarenakan lapisan film cairan non Newtonian di sekitar bubble lebih tebal akibat viskositas yang tinggi.

4. Semakin tinggi rasio kecepatan superfisial gas terhadap cairan semakin panjang bubble untuk setiap jenis cairan uji. Untuk aliran dua fase argon-cairan non Newtonian, panjang bubble semakin pendek seiring bertambahnya konsentrasi larutan polyacrylamide.

5. Data penelitian aliran dua fase argon-cairan non Newtonian dibandingkan dengan pola aliran homogeneous $(\alpha=\beta)$, Armand et al (1946), $\alpha=0.833 \beta$ dan Kawahara et al (2002) untuk aliran dua fase nitrogen-water di pipa circular, $\alpha=\sqrt{0.03 \beta} /(1-\sqrt{0.97 \beta})$ Penelitian kali ini, untuk masing-masing jenis cairan uji mendekati pola aliran homogeneous meliputi pola aliran slug dan plug.

\section{DAFTAR PUSTAKA}

[1] SOMCHAI WONGWISES. 2005. Flow pattern, pressure drop and void fraction of two-phase gas-liquid flow in an inclined narrow annular channel. Experimental Thermal and Fluid Science, Vol. 30. pp. 345354.

[2] KAWAHARA, A., MOHAMED H. MANSOUR, MICHIO SADATOMI, WEN ZHE LAW, HIROKI KURIHARA, HASLINDA KUSUMANINGSIH. 2015. Characteristics of gas-liquid two-phase flow through a sudden contraction in rectangular microchannels. Experimental Thermal and Fluid Science, Vol. 66. Pp. 243-253.

[3] AWALUDDIN, SLAMET WAHYUDI, AGUNG SUGENG WIDODO. 2014. Analisis aliran dua fase (udara-air) melalui belokan $45^{\circ}$. Jurnal Rekayasa Mesin., Vol. 5, No. 3, pp. 217-224

[4] YANG, Z.C., BI, Q.C., LIU, B., HUANG, K.X., 2010. Nitrogen/Non-Newtonian Fluid Two-Phase Upward Flow in Non-Circular Microchannels. International Journal of Multiphase Flow, Vol. 36, pp. 6070.

[5] KAWAHARA, A., MORI, A., LAW, W.Z., YONEMOTO, Y., MANSOUR, M.H., \& SADATOMI, M., (2016). Two-phase Pressure Drop for Gas and Non-Newtonian Liquid Flows through Circular Microchannel. Jepang: J-STAGE.

[6] MANSOUR, H. MOHAMED, AKIMARO KAWAHARA, MICHIO SADATOMI. 2015, Experimental Investigation of Gas-non Newtonian Liquid Two-Phase Flow from T-junction Mixer in Rectangular Microchannel. International Journal of Multiphase Flow, Vol 72, pp. 263-274. 
[7] KAWAHARA, A., CHUNG, P. M. Y. dan KAWAJI, M., 2002, Investigation of two-phase flow pattern, void fraction and pressure drop in a microchannel, International Journal of Multiphase Flow, Vol. 28, pp. 1411-1435.

[8] GARSTECKI, P., FUERSTMAN, M. J., STONE, H. A. dan WHITESIDE, G.M., 2006, Formation of droplets and bubbles in a microfluidic T-junction-scaling and mechanism of a break-up, Lab on a chip, Vol. 2, pp. 437-446.

[9] AGOSTINI, B., REVELLIN, R. dan THOME, J. R., 2008, Elongated bubbles in microchannels. Part I: Experimental study and modeling of elongated bubble velocity, International Journal of Multiphase Flow, Vol. 34, pp. 590-601.

[10] STEIJN, VOLKERT, KREUTZER, MICHIEL dan KLEIJN, CHRIS. 2007. PIV study of the formation of segmented flow in microfluidic T-junctions. Chemical Engineering Science. Vol. 62. Pp. 7505-7514. DOI. 10.1016/j.ces.2007.08.068

[11] ARMAND, A. A., 1946. The resistance during the movement of a two-phase system in horizontal pipes, Izv. Vses. Teplotekh. Inst., Vol. 1, (AERE-Lib/Trans 828) pp. 16-23. 